\title{
Some comments on Dr Iglesias's paper, 'In vitro fertilisation: the major issues'
}

\author{
Jean M Mill Formerly of the Department of Logic and Metaphysics, University of Edinburgh
}

\section{Author's abstract}

In an article in an earlier edition of the Journal of Medical Ethics (1) Dr Iglesias bases her analysis upon the mediaeval interpretation of Platonic metaphysics and Aristotelian logic as given by Aquinas. Propositional forms are applied to the analysis of experience. This results in a very abstract analysis. The essential connection of events and their changing temporal relationships are ignored. The dichotomy between body and soul is a central concept. The unchanging elements in experience are assumed to be more real than the actual world of experienced process. Such a view makes the analysis of the temporal factors in experience impossible. Its abstractness is quite unsuitable for the analysis of the ontological structure and development of the neonate from fertilisation to birth.

$A N$ Whitehead made the notion of organism central to his philosophy. He refused to place human experience outside nature, or admit dualism. His philosophy of organism is an attempt to uncover the essential elements connecting human experience with the physical and biological sciences. Time, change and process are, in his view, more real than the static abstractions obtainable by the use of the fallacy of misplaced concreteness. Use of the latter negates the essential connectedness of events and the importance of temporality and change (2). In this paper I argue that the embryo, being an organism, is not analysable in terms of thinghood. It is a process. To apply Aristotelian logical concepts to it is to distort the real nature of the datum.

Dr Iglesias states that we must know what things are in order to discover how we should treat them and what respect they are due (1). These two enquiries, the ontological and the moral, are correlative. Unless she is using the term 'thing' to include process, this ontological assessment of the status of the embryo, and the moral values predicated of it, are questionable. Predicating moral values to things throws no light upon the problem of the changing values to be ascribed within a process. Dr Iglesias assumes that the

\section{Key words}

Process; soul; individuation; immediacy; personhood; becoming; being. conceptus is a human person. This is debatable. The alternative view is well stated with reference to Catholic theology in chapter three of John Mahoney's book entitled Bioethics and Belief (3), where he quotes Aquinas, 'Our flesh is conceived before it is animated'. Up until the mid-nineteenth century this was the accepted Catholic view. I understand it is still the official teaching of the Church.

The notion of the soul, which is a conceptual construct, an omnibus term referring to man's selfawareness, conscience, volition, etc, (ie our experience of ourselves as beings able to control and reflect upon our behaviour) is essentially non-temporal. Its essential function is to assure us that throughout all the vicissitudes of growth and change there is an enduring non-temporal entity which will even survive death. It seems strange that people should discuss at what instant of time the soul enters the body. This entails viewing time as a one-dimensional irreversible parameter of the Newtonian space-time continuum. Otherwise we do not have the concept of 'an instant'. Is the choice of any one instant rather than another not bound to be arbitrary?

The answer given depends upon whether or not one thinks that being (the essence of a thing) precedes becoming (the thing's acquisition of attributes through which it can manifest its nature). If being precedes becoming God, as it were, is 'done with' the creation of an individual in the first instance of his or her existence. What happens thereafter is irrevocably given.

Alternatively, instead of taking God as the efficient cause (ie that which makes a thing what it is, the creative principle) of a person's being, one can view N Him as the teleological cause (the end aimed at, that at which purposeful action is aimed and which governs 6 the development or design inherent in any process). Every living creature has an aim towards which it is $\stackrel{?}{+}$ progressing as it matures. Instead of accepting a 7 dichotomy between matter and mind, body and soul, one can accept their fusion and look upon the soul as essentially embodied, and body as 'solidified soul'. Having created human beings and given them the ability to pro-create and 'hand on' their genetic inheritance by the fusion of male and female gametes, - thus allowing for novelty, - the Creator may be thought to be the mediate cause of every individual 
creature, but to have set before His creatures a teleological aim towards which every individual in each generation is striving. The creature, in maturing, is working towards his true being, or essential God-given nature.

Whitehead states that ' $L$ ife is a bid for freedom . . . The doctrine of the enduring soul with its permanent characteristics is exactly the irrelevant answer to the problems which life presents. The probiem is, How can there be originality?'(4).

The static view, based upon applying the mediaeval interpretation of Aristotle's logic to solve ontological problems, raises many difficulties, for example the relation of body and soul; interpersonal awareness; the fact that two different kinds of divine causation, mediate for the body and immediate for the soul are necessary for the creation of an individual human person; the status of organisms; and our experience of temporal growth and process, to mention a few. If the soul is infused into the body at conception, how do we gain knowledge of this? Do we not require to take up a God-eyed position to come by it? We cannot know it by self-reflection, nor by observation. To maintain such a position is surely an example of what in Edinburgh we used to refer to as 'the Elginbrod fallacy' because of the epitaph:

'Here lie I Martin Elginbrod,

Have mercy on my soul, Lord God.

As I would do if I were God,

And Thou wert Martin Elginbrod.'

If we cannot know when ensoulment occurs we are only 'playing safe' by assuming that it occurs at conception. Surely to forfeit the gains in medical understanding which embryo research is producing is too high a price to pay for 'erring on the safe side'.

Dr Iglesias holds that there is no such thing as biological life. This view is closely associated with her reason for maintaining that the conceptus is a human person. All life, she maintains, is sustained and transmitted through individuals. Her view partially rests upon pivoting from one to the other meaning of the word 'individual'. It means both 'unitary' and 'having unique human characteristics'. One must accept that when male and female gametes fuse to form the one-celled embryo, then we have a new entity. But unitariness and individuality are not identical concepts. It should also be noted that the word 'immediately' has also two distinct meanings. When Pope Pius XII stated that one might concede that the human body had evolved from pre-existing material, but held that the soul is created immediately by God, he was drawing attention to the fact that, on this view, the physical creation of the human body is mediated by the intervention of the parents, whereas God's creation of the soul is immediate, ie not mediated through human inheritance (5). It is possible that people have mistaken his meaning and have assumed that he was claiming that the individual's soul was created and infused into the newly created embryo without any temporal delay?

Philosophically, the problem of individuation as it concerns person-hood is central to this issue. If one allows both that the embryo is a unity and that it is human, what else can it be but a person? No other human entity is conceivable. If, however, one holds to the metaphysical position that 'becoming' must precede 'being' (that as the human body matures, and man's faculties develop towards their essential 'aim' or 'being', so the non-physical, spiritual aspects of man's being also develop towards full person-hood) then one will view the embryo as 'potentially human' not as 'a human being with potential'.

If God's causality is teleological and there is no dichotomy between body and soul then the fact of embryonic development will be regarded as of more importance than the analysis of the qualities attributable to the embryo at any one stage of its development. It seems extraordinary that some people propose to settle the question as to whether or not micro-biological techniques ought to be applied in twentieth century medicine by a consideration of how, in terms of the mediaeval philosophers' interpretation of Aristotle, his categories of thought apply to the concept of being, and the effect this has on the doctrine of ensoulment.

Qualities can be predicated of material which is undergoing change when one abstracts from the temporal factors of the situation. They cannot be predicated of the process itself. The embryo can at different times be considered to be a two, four or eightcelled organism on this view, but one cannot predicate cleavage or any process of change to it. Dr Iglesias has to apply the 'Principle of Unity' and the 'Principle of Potentiality' in an attempt to relate the static concepts of her ontological theory to the changing datum which is the person in his development from conception to adult-hood. Let us examine these principles and how they relate to the discussion of the ontological and moral status of the embryo.

We are told that the 'Principle of Unity' means that a human being, like any other creature, is just one entity, one being, and not a composite of two things. One is tempted to comment 'How splendid!' We now have one entity and can happily apply our Aristotelianbased classificatory schema to it whether it is manifesting itself as an embryo or as a mature human adult. The choice is not really between two things, but between the concept of thing-hood and that of process. Because there is a nexus, an individuality whereby we recognise that a process relates to a single experiencing subject, this subject is now being treated as if it were a static entity. From a pragmatic viewpoint it certainly is no such thing. Dr Iglesias states that 'The inseparability of what a thing is and its capacities is particularly manifested in its organic continuity, in its being always the same organism'. If there is no such thing as biological life, can there be such a thing as organic continuity? I doubt it! Leaving aside this query, although it is not insignificant, might I suggest 
that one cannot have it both ways! An organic continuity is not a thing. It does not exemplify sameness, although it does exemplify individuation. This is on account of its prehensive relationships with all other developing organic unities. A capacity to enter into relationships within a changing environment and to assert one's individuality in so doing is quite different from being endued with qualities that inhere in one's unchanging state of being.

Dr Iglesias affirms that 'If we are to make sense of our existence now as human personal beings, then we must admit that whatever capacities we have now, have developed from what we were in the beginning. Our present abilities are only explicable if there was always a presence of the inherent capacity for these abilities in the human organism'. This is to deny the reality of process and of development. It is true that each item in the world lies between what has been and what will be, but if what might be is completely circumscribed by what has been, where is the possibility of novelty and progress in any new creation? Unless one is going to assert that God infuses novelty at the moment of conception, thus making a nonsense of the notion of evolutionary change, sheer unending repetition of what has been, is, and always will be, appears to be the outcome of holding such a view of potentiality. It is potentiality for repetition, not for creative advance. As the moral dimension of a universe that admits process as being ultimately real depends upon the notion of creative advance, this static ontological view can be said to be a denial of the possibility of moral value, and the basis for accepting an authoritarian classification of right and wrong.

This 'Principle of Potentiality' treats time and temporal duration as being totally unreal. What is meant by the phrase 'from the beginning'? One cannot both affirm and deny the reality of temporal duration without becoming incoherent. The entity to which the 'Principle of Potentiality' would seem to relate is, I would suggest, a very queer kind of thing. Our capacities, which we now have, have developed from what we were in the beginning, (whenever that is supposed to be). In the following sentence we are assured that these capacities did not develop. They are only explicable if there was always, (whatever that means,) an inherent capacity for these abilities to be present. What is inherent can become actual. On this view one must accept that prior to the actualisation of the capacity it was really there. The undeveloped organism can then be classified as having the same ontological structure as it manifests in its maturity. If one is not willing to take the notion of time seriously, (and classical metaphysical theories abstract from the temporal reality of experience) then one is bound to end up in a most dreadful muddle. This is well illustrated when $\mathrm{Dr}$ Iglesias states that the development of a living entity becoming what it is capable of being is a process, but that the entity itself, and its coming to be, is not. She avers that 'at any particular time the entity is 'in toto' or it is 'not at all'. I would claim that the second option is the correct one! A process is not an entity. How can one claim that a 'coming to be' is an entity? 'Becoming' is said to be a process, but 'coming to be' is an entity. Can one rationally make a meaningful distinction between 'becoming' and 'coming to be'? If a process is not an entity, and an embryo is correctly to be defined as a process, then this reason for asserting that the embryo is human is not valid. It would only be valid if the ontological analysis of processes in terms of entities were defensible. I would submit that the attempt to make it so lands one in self-contradictory utterances about the nature of time, development, and potentiality.

When Dr Iglesias claims that one cannot speak of biological life because it is sustained and transmitted through individuals, she is demonstrating her predilection for treating all data in terms of thinghood. One individual thing, with its range of qualities inhering in its own piece of substance is totally isolated from all other things. It is correct that the notion of biological life becomes untenable if one starts from this spatialised and abstract view of what constitute the ultimately real data of experience. One can count them, make heaps of them, but one cannot fuse them or discover any inter-relations between them, nor impute development to them. The only contact that they have with other things is their external spatial relations, - real or imaginary, - and the fact that the same abstract qualities can be predicated of some of them. This includes them as examples of the same universal concept. On the other hand, the essential characteristic of a process, (how its individuality is formed and expressed) lies in its ability to relate to other processes. The final cause, or aim, which all biological life strives towards is the production of a unique individual from undifferentiated or potential material. One of the essential characteristics of a person is his or her ability to relate to other persons. Herein lies one of the basic facts of morality. Morality is concerned with how we, as persons, develop and relate to other persons and to environmental processes. Until the embryo becomes dependent upon, or is related to, another person, I can see no reason for regarding it as human or personal. It seems correct to call it biological. Here we have an organism with a specific aim, (that of developing human characteristics). The embryo is the result of the fusion of two living biological gametes. Its structure includes the 'blueprint' for the physical form that the developing individual will assume. Some people have argued that the fact that the genetic typing of the individual is contained within the embryo points to the whole essence of the actual person, both physical and spiritual, being 'given'. God, as it were, is thought to create the individual 'in toto', then to withdraw and leave it to the mediated causality of physical development to manifest this creature's individuality. Is this view not really a de-personalisation of human life? Does it not make man a mere artefact of his 
Creator? God is viewed rather like a naval architect who designs and gives all the specifications for the building of ships, but neither constructs nor sails them, having specified and produced all that is necessary for their making and voyaging.

I would suggest that one must take the notion of process seriously and consider the embryo as an organism, (the first stage in the development of a human being). At the embryonic stage of human development, when the cells reproduce themselves by cleavage, these cells are toti-potential. In a letter to The Times (6) last April Sir Andrew Huxley suggested that in normal development most of these cells are destined to form placental tissue and that in this mass of cells a potential human being has not even begun to take form.

It would be extraordinary if the fusing of two gametes could immediately produce a human person. I would suggest that time and development are required before the fusion of two biological cells could possibly manifest human attributes. Furthermore, I would maintain that essentially our humanity depends upon our ability to react to other persons. The evidence suggests that it is after implantation in the womb, (the embryo's initial experience of interaction with another person,) that the first manifestations of human characteristics become evident. If one does not accept the separability of the physical and the spiritual aspects of person-hood, then one will accept that the onset of the recognisably human physical features of the body are a 'sine qua non' of the possibility of the fetus having any spiritual humanity.

If God is accepted as the teleological cause and not the efficient cause of creation, then the possibility of novelty, free-will, and interpersonal relationships become much simpler to understand. Also the temporal aspects of development and change can be extrapolated. It would then seem that the human person's development from his biological origin as an embryo, to his full human stature as an adult person is gradual. Such a theory can be rationally and emotionally accepted without denying the sovereignty of God, by discarding a static Aristotelian-based logical analysis of the ontological structure of the universe and of the morality implicit in our human state.

fean M Mill, MA PhD, Critriach, Acharacle, Argyll. Recently widowed, Dr Mill now pursues an interest in medical ethics. She is indebted to Professor David Baird and the staff at the Centre for Reproductive Biology, University of Edinburgh; to Professor Allan Templeton of the Department of Obstetrics and Gynaecology at the University of Aberdeen; and to the Reverend Dr Kenneth Boyd, Edinburgh University, for their willingness to discuss research issues and facilitate access to published and unpublished literature on bio-medical topics.

\section{References}

(1) Iglesias T. In vitro fertilisation: the major issues. Fournal of medical ethics 1984; 10: 32-37.

(2) Whitehead A N. Process and reality. An essay in cosmology. Gifford lectures delivered in the University of Edinburgh during the session 1927-28. Published at Cambridge at the University Press, 1929.

(3) Mahoney J. Bioethics and belief. London: Sheed and Ward, 1983: 59.

(4) See reference (2): 145.

(5) Pope Pius XII. Encyclical letter. Humani generis No 36. AAS 42 (1950); 575.

(6) Huxley Sir A. (Letter). The Times 1985 Apr 6: 9(col 4). 